\title{
Successful in the long run? A meta-regression analysis of persistent firm profits
}

\section{Journal Article}

\section{Author(s):}

Hirsch, Stefan

Publication date:

2018-02

Permanent link:

https://doi.org/10.3929/ethz-b-000167786

Rights / license:

In Copyright - Non-Commercial Use Permitted

Originally published in:

Journal of Economic Surveys 32(1), https://doi.org/10.1111/joes.12188 


\title{
Successful in the long run? A meta-regression analysis of persistent firm profits
}

\begin{abstract}
We study the profit persistence literature by applying meta-regression analysis (MRA) to a set of 36 empirical papers which analyze the persistence of abnormal firm profits over time. The analyzed literature provides evidence for a mediocre degree of persistence in abnormal profits. An initial analysis of the distribution of reported profit persistence estimates reveals some degree of excess variation. This points towards publication bias that favors significant results independent of their algebraic sign. The MRA, however, reveals that publication bias is particularly favoring results that indicate profit persistence and thus contradict the neoclassical model of perfect competition. Moreover, the MRA enables to control for heterogeneity driven by the study design. We find that the analyzed country (developing vs. developed), the applied econometric approach as well as the analyzed period of time are significant drivers of heterogeneity in reported persistence estimates.
\end{abstract}

Keywords: Firm performance; Abnormal profits; Meta-regression analysis

\section{Introduction}

Analyzing the causes of persistence in firm profits is a determining and continuously growing field in economic literature (Goddard et al., 2005). From an entrepreneurial point of view outperforming the market by achieving and sustaining profits above the competitive norm is a primary objective. Antitrust authorities on the contrary are generally interested in perpetuating a certain degree of competitive pressure which ensures that such abnormal profits prevail in the short run only.

Economic theory on the persistence of abnormal firm profits emanates from the neoclassical model of perfect competition (e.g. Schwalbach et al., 1989). This standard textbook model proceeds on the assumption of a perfectly competitive market where abnormal firm profits are instantaneously driven back to the competitive norm - usually assumed to be zero or average market profitability (Carlton and Perloff, 2005). The resulting research hypothesis therefore states that abnormal profits are only feasible in the very short run. However, firms that continuously outperform the market can frequently be observed across economic sectors (Hirsch et al., 2014). Theoretical approaches focusing on such deviations from the state of perfect competition have particularly emerged within the realms of industrial organization (IO) and strategic management. Bain's (1956) classical IO theory as well as Porter's (1980) 'Market-Based-View' attribute the potential of firms to generate persistent abnormal profits to industry-specific characteristics such as concentration or entry barriers. In contrast, approaches of strategic management such as the 'Resource-Based-View' 
(RBV) ascribe persistent deviations of profits from the competitive norm to firm-specific valuable and inimitable resources (e.g. Barney, 1991).

Earlier attempts to empirically assess the drivers of abnormal firm profits are based on cross-sectional data ${ }^{1}$ and therefore of static nature (e.g. Schmalensee, 1985). Most of those studies apply variance decomposition techniques such as analysis of variance (Rumelt, 1991; McGahan and Porter, 1997) or more recently hierarchical linear modeling (e.g. Short et al., 2006) to estimate the percentage contribution of firm structure, industry and country affiliation, or time to variance in abnormal firm profits. Some studies additionally assess the effect of structural factors such as firm size or industry concentration (e.g. Chaddad and Mondelli, 2013). Starting with Mueller (1986) a strain of research referred to as profit persistence literature has evolved. Those studies analyze the dynamic behavior and thus the persistence of abnormal firm profits over time (e.g. Goddard et al., 2005; Gschwandtner, 2012). The predominant econometric approach of this fast growing literature is an autoregressive (AR) model of order one where abnormal firm profit in $t$ is regressed on its lagged value $(t-1)$. The degree of persistence of abnormal profits is then captured by the autoregressive coefficient usually referred to as the $\hat{\lambda}$-value. The empirical literature provides mixed evidence on the degree of profit persistence with varying results across countries, sectors, time spans and estimation techniques. To obtain insight into the drivers of heterogeneity in reported results we employ the approach of meta-regression analysis (MRA).

Although obtained by means of different econometric estimators, the profit persistence measure $\hat{\lambda}$ has a uniform interpretation across the literature. The fact that $\hat{\lambda}$ quantifies the same economic concept across primary studies makes it a suitable measure to be studied by means of MRA (Oczkowski and Doucouliagos, 2014). MRA is a type of meta-analysis that can be described as regression analysis of primary regression analyses (Stanley and Jarrell, 1989). It therefore provides a framework to evaluate and summarize empirical results on a similar economic phenomenon obtained from different study designs and estimation approaches (Nelson and Kennedy, 2009). Stanley (2001) discusses the usefulness of metastudies to analyze empirical economic research and concludes that MRA has considerable advantages compared to narrative literature reviews. MRA has its roots in natural science (e.g. DerSimonian and Laird, 1986) however, since the 1990s it has increasingly been applied in economic research (e.g. Jarrell and Stanley, 1990; Card and Krueger, 1995; Longhi et al., 2005; Card et al., 2010; Bakucs et al., 2014; Oczkowski and Doucouliagos, 2014; Valickova et al., 2015; Wang and Shailer, 2015; Demena and van Bergeijk, 2016). 
We revisit the profit persistence literature by applying MRA to a set of 36 papers which report 413 profit persistence estimates $\hat{\lambda}$. Thus the purpose of this article is to analyze the distribution of reported $\hat{\lambda}$-values and to provide a summary of effect size. The findings help to evaluate whether systematic deviations of firm profits from the competitive norm prevail over time or if competitive forces are strong enough to erode such deviations in the short run. We also test for publication biases that emerge when editors and reviewers prefer statistically significant results (Stanley and Jarrell, 1989). In those cases studies with insignificant results will remain unpublished (Stanley, 2005). In addition, we assess how far factors related to the research design such as the analyzed region, industry or the applied econometric approach drive variability in $\hat{\lambda}$-values. Similar to Oczkowski and Doucouliagos (2014) we improve the standard MRA approach by employing estimation techniques that correct for within author correlation of standard errors as well as for the unequal number of reported $\hat{\lambda}$-coefficients by individual authors. The present MRA is based on the 'MetaAnalysis of Economics Research Reporting Guidelines’ recommended by Stanley et al. (2013).

The next section provides an overview of the profit persistence literature with focus on the analyzed empirical effect $(\hat{\lambda})$ as well as the employed research designs. Subsequently, the meta-data is described in section 3. Section 4 first provides the MRA framework and results. Finally we provide conclusions and suggestions for future firm profitability research.

\section{Profit persistence literature}

To identify relevant studies that estimate the persistence in abnormal firm profit a literature search has been conducted between June and August 2015. The following databases were searched for all meaningful combinations of the keywords firm, profit, profitability, persistence, sustained, long-term/run, dynamic and panel: Academic Search Premier, AgEcon Search, Business Source Premier, Econlit, Google Scholar, Science Direct, Scopus, SSRN eLibrary, and Wiley Online Library. Moreover, we examined the reference list of each paper by means of snowballing techniques (Longhi et al., 2005). The initial pool of 72 potentially relevant published and unpublished studies was then restricted to those studies that apply autoregressive (AR) processes for the quantification of profit persistence.

AR models have first been introduced to the profit persistence literature by Mueller (1986). Subsequently, a series of contributions based on the AR approach has emerged focusing on profit persistence in diverse countries and economic sectors (e.g. Schohl, 1990; 
Odagiri and Yamawaki, 1990; Glen et al., 2001; Yurtoglu, 2004). The initial AR approach has the following form (Mueller, 1986):

$\pi_{i, t}=\alpha_{i}+\lambda_{i} \pi_{i, t-1}+\varepsilon_{i, t}$

with $\pi_{i, t}$ reflecting profitability of firm $i$ in year $t$ normalized by the competitive norm which is usually proxied by average profitability of the industry in which the firm operates ${ }^{2} . \pi_{i, t}$ measures the degree by which a firm outperforms its industry and can therefore be interpreted as abnormal profitability. The bulk of literature has employed accounting ratios such as return on assets, return on sales, or return on capital to proxy firm profitability while only a few studies utilize market values such as Tobin`s Q or market-to-book ratios. $\varepsilon_{i, t}$ is a classical zero mean i.i.d. error term. The estimated AR coefficient $\hat{\lambda}_{i}$ is the key parameter of interest as it reflects persistence of abnormal profits of firm $i$ from period to period. Some earlier studies estimate equation (1) individually for each firm using OLS. Subsequently, mean $\hat{\lambda}_{i}$ across all analyzed firms serves as the measure for persistence (e.g. Geroski and Jacquemin, 1988). This implies that precision measures for individual estimates (standard errors, p-values, or t-values) are not reported. The availability of precision measures is, however, a crucial factor for the feasibility of MRA leading to the exclusion of those studies. ${ }^{3}$ More recent articles quantify profit persistence by using pooled-OLS regressions (e.g. Roberts, 1999) or by means of panel data techniques such as Arellano and Bond's General Method of Moments (GMM) estimator (Goddard et al., 2005). Equation (1) is then modified to:

$\pi_{i, t}=\alpha+\lambda \pi_{i, t-1}+\varepsilon_{i, t}$

Estimating the pooled model yields a single profit persistence measure $(\hat{\lambda})$ for the entire sample of firms for which precision values are commonly reported. Several studies (e.g. Hirsch and Gschwandtner, 2013) include additional explanatory variables $X_{k}$ which capture structural characteristics such as firm size or industry concentration extending (2a) to:

$\pi_{i, t}=\alpha+\lambda \pi_{i, t-1}+\sum_{k} \alpha_{k}\left(X_{k, i, t}\right)+\varepsilon_{i, t}$

Studies based on (2a) and (2b) constitute the core profit persistence literature. The AR coefficient $\hat{\lambda}$ is the most frequently used and best available empirical measure of profit persistence. For any analyzed sample of firms $\hat{\lambda}$ quantifies fluctuations of abnormal profits over time and hence measures profit persistence. Moreover, $\hat{\lambda}$ is a proxy for the adjustment speed at which competitive forces push abnormal profits back to the long-run prediction of 
the AR process. Abnormal profits are eroded over time in proportion to $\hat{\lambda}, \hat{\lambda}^{2}, \hat{\lambda}^{3}, \hat{\lambda}^{4}, \ldots, \hat{\lambda}^{T}$ for periods $t=1,2,3,4, \ldots, T$. For example, $\hat{\lambda}=0.5$ denotes that $12.5 \%$ of abnormal profit generated in $t=0$ persist in $t=3$ (Hirsch, 2014). Hence, the closer $\hat{\lambda}$ is to one the higher the stability and thus persistence of abnormal profits. In this case firms have specific competitive advantages in accordance with the theoretical approaches of IO or the RBV. In contrast, the closer $\hat{\lambda}$ is to zero the faster the reduction of abnormal profits and the lower their persistence. ${ }^{4}$ Such results support the neoclassical model of perfect competition. Moreover, negative $\hat{\lambda}$ values between zero and minus one indicate strong fluctuations of abnormal profits between periods and therefore also point towards low persistence and the validity of the model of perfect competition. As $\hat{\lambda}$ captures the dynamics of abnormal profits between periods it can also be interpreted as a measure for competition in the Schumpeterian sense (Geroski, 1990; Yurtoglu, 2004). To ensure a converging pattern of abnormal profits $-1<\hat{\lambda}<1$ needs to hold which implies that unit root processes or exploding patterns with $|\hat{\lambda}|>1$ are not meaningful in a Schumpeterian way of competition and hence should not occur (Hirsch, 2014). In accordance none of the identified studies reports results where $\hat{\lambda} \leq-1$ or $\hat{\lambda} \geq 1^{5}$.

To summarize, three types of 'desirable' results can occur that are in line with economic theory: (i) Profit persistence indicated by statistically significant $\hat{\lambda}$-values in the interval $0<\hat{\lambda}<1$. Theoretically those results are supported by IO or the RBV. (ii) Immediate erosion of abnormal profits reflected by insignificant $\hat{\lambda}$-values close to zero. (iii) Significant negative $\hat{\lambda}$-coefficients in the interval $-1<\hat{\lambda}<0$. The latter two are theoretically supported by the neoclassical model of perfect competition.

$\hat{\lambda}$ is a scale free measure which quantifies an uniform economic concept making its interpretation comparable across literature. We hence focus on studies based on (2a) and (2b) and assess in how far heterogeneity in reported persistence values is driven by study design characteristics. Moreover, we analyze whether the literature is affected by publication bias.

While the application of AR models dominates the profit persistence literature a few studies employ deviating approaches. The initial literature (e.g. Mueller, 1977) is based on a polynomial convergence model (PCM) which models the adjustment process of abnormal profits by regressing the latter on the inverse of time. The estimated coefficient reflects the speed at which abnormal profits converge on the long-run level and can hence be used as a persistence measure. However, as this coefficient has a different interpretation than the AR coefficient $\hat{\lambda}$, studies based on the PCM approach are excluded from the present analysis. McGahan and Porter (2003) implement sequential weighted-least-squares to proportion the 
persistence of abnormal profits into a firm and industry component. We exclude this study as it does not derive a coefficient of persistence comparable to the $\hat{\lambda}$-value but rather reveals the percentage contribution of firm structure and industry affiliation to the degree of profit persistence. Finally, a small set of studies uses structural time series analysis (STSA) (Cable and Jackson, 2008; Cable and Mueller, 2008). Those papers conduct case studies with a focus on a small sample of four to five firms whose profitability is analyzed over long periods of up to 50 years in order to derive a long-run trend of abnormal profits. This value reflects the long-run equilibrium of abnormal firm profits and hence is not comparable to the persistence value $\hat{\lambda}$. Consequently STSA studies were also excluded from the present analysis.

The final sample of 36 profit persistence studies is summarized in Table 1. In cases where several versions of an article were available we ensured that only the latest version is considered. Consequently, only 4 unpublished working papers remained in the sample. As the majority of articles are working papers before publication we suggest that working papers should only be treated differently from peer reviewed published work if the time span since completion is long enough to assume that several unsuccessful publication attempts have been carried out. For recent working papers it is unclear whether they will remain as grey literature in the file drawer or if they will be published in their current form. We consider all working papers which have been finalized less than 4 years ago (i.e. after 2011) as recent which implies that none of the 4 identified working papers is considered as a 'true' working paper.

29 articles report several profit persistence estimates which are the result of varying specifications of (2a) or (2b), relating to different estimation techniques (Saona Hoffmann, 2011), countries (Goddard et al., 2005), industry subsectors, firm groups (Goddard et al., 2013) or time periods (Gschwandtner, 2012). The total number of profit persistence estimates $\hat{\lambda}$ in our sample amounts to 413 . Mean and median $\hat{\lambda}$-values per study are reported in Table 1.

Table 1 reveals that the included studies have been published during the period 19932015. It can be observed that the literature focuses on a diverse set of developed and developing countries. As regards analyzed economic sectors a large portion of studies concentrates on entire manufacturing industries. A few articles also focus on manufacturing subsectors such as the food industry (Alarcon and Sanchez, 2013; Hirsch and Gschwandtner, 2013) or are restricted to publicly quoted firms (Schmidt, 2014). Initiated by Goddard et al. (2004a; 2004b) the focus has shifted to specific service sectors such as banking. Table 1 also indicates that the econometric approaches applied for the estimation of (2a) and (2b) are either pooled OLS or GMM while a few studies employ the fixed effects estimator. 
Table 1: Overview of profit persistence studies based on autoregressive models

\begin{tabular}{|c|c|c|c|c|c|c|c|}
\hline Authors & Countries & $\begin{array}{l}\text { Time } \\
\text { span }\end{array}$ & Industry & $\begin{array}{l}\text { No. of } \\
\text { firms }\end{array}$ & Method & $\begin{array}{l}\text { No. of } \\
\text { Estimates }\end{array}$ & $\begin{array}{c}\text { Mean } \\
\text { (Median) } \\
\hat{\lambda}\end{array}$ \\
\hline Droucopoulos \& Lianos (1993) & Greece & 1963-1988 & Manufacturing & n.a. & OLS & 20 & $\begin{array}{r}0.819 \\
(0.828)\end{array}$ \\
\hline Geroski et al. (1993) & UK & 1972-1983 & Manufacturing & 721 & $\begin{array}{l}\text { GMM \& } \\
\text { OLS }\end{array}$ & 4 & $\begin{array}{r}0.582 \\
(0.491)\end{array}$ \\
\hline Bhargava (1994) & UK & 1979-1984 & $\begin{array}{l}\text { Manufacturing } \\
\text { and service }\end{array}$ & 114 & GMM & 4 & $\begin{array}{r}0.295 \\
(0.240\end{array}$ \\
\hline Dickerson et al. (1997) & UK & 1948-1977 & $\begin{array}{l}\text { Manufacturing } \\
\text { and service }\end{array}$ & 2,941 & $\begin{array}{l}\text { Fixed } \\
\text { effects }\end{array}$ & 4 & $\begin{array}{r}0.526 \\
(0.525)\end{array}$ \\
\hline Roberts (1999) & U.S. & 1977-1993 & Manufacturing & 42 & OLS & 2 & $\begin{array}{r}0.715 \\
(0.715)\end{array}$ \\
\hline McNamara et al. (2003) & U.S. & 1978-1997 & Manufacturing & 5,700 & OLS & 1 & $\begin{array}{r}0.674 \\
(0.674)\end{array}$ \\
\hline Goddard et al. (2004a) & $\begin{array}{l}\text { Denmark } \\
\text { France } \\
\text { Germany } \\
\text { Italy } \\
\text { Spain } \\
\text { UK }\end{array}$ & 1992-1998 & Banking & $\begin{array}{r}32 \\
57 \\
316 \\
82 \\
60 \\
118\end{array}$ & $\begin{array}{l}\text { GMM \& } \\
\text { OLS }\end{array}$ & 12 & $\begin{array}{r}0.284 \\
(0.275)\end{array}$ \\
\hline Goddard et al. (2004b) & $\begin{array}{l}\text { France } \\
\text { Germany } \\
\text { Italy } \\
\text { Spain } \\
\text { UK }\end{array}$ & 1992-1998 & Banking & $\begin{array}{r}43 \\
307 \\
72 \\
56 \\
105\end{array}$ & GMM & 15 & $\begin{array}{r}0.392 \\
(0.501)\end{array}$ \\
\hline Lima and Resende (2004) & Brazil & 1992-1998 & Manufacturing & 201 & GMM & 4 & $\begin{array}{r}0.139 \\
(0.134)\end{array}$ \\
\hline Villalonga (2004) & U.S. & 1981-1997 & $\begin{array}{l}\text { Manufacturing } \\
\text { and service }\end{array}$ & 1,641 & GMM & 6 & $\begin{array}{r}0.459 \\
(0.512)\end{array}$ \\
\hline Chacar and Vissa (2005) & $\begin{array}{l}\text { U.S. } \\
\text { \& India }\end{array}$ & 1989-1999 & Manufacturing & 8,887 & $\begin{array}{l}\text { Fixed } \\
\text { effects }\end{array}$ & 2 & $\begin{array}{r}0.435 \\
(0.435)\end{array}$ \\
\hline Elsayed and Paton (2005) & UK & $1994-2000$ & $\begin{array}{l}\text { Manufacturing } \\
\text { and service }\end{array}$ & 227 & GMM & 2 & $\begin{array}{r}0.053 \\
(0.053)\end{array}$ \\
\hline Goddard et al. (2005) & $\begin{array}{l}\text { Belgium } \\
\text { France } \\
\text { Italy } \\
\text { Spain } \\
\text { UK }\end{array}$ & 1993-2001 & $\begin{array}{l}\text { Manufacturing } \\
\text { and service }\end{array}$ & $\begin{array}{l}1,348 \\
4,620 \\
2,173 \\
2,030 \\
1,511\end{array}$ & GMM & 55 & $\begin{array}{r}0.352 \\
(0.355)\end{array}$ \\
\hline Bhattacharya (2007) & Japan & 1985-1997 & Manufacturing & 76 & OLS & 3 & $\begin{array}{r}0.728 \\
(0.758)\end{array}$ \\
\hline $\begin{array}{l}\text { Crespo Cuaresma and } \\
\text { Gschwandtner (2008) }\end{array}$ & U.S. & 1950-1999 & Manufacturing & 156 & GMM & 1 & $\begin{array}{r}0.435 \\
(0.435)\end{array}$ \\
\hline Eklund and Wiberg (2008) & Europe & 1984-2004 & n.a. & 293 & $\begin{array}{l}\text { Fixed } \\
\text { effects }\end{array}$ & 3 & $\begin{array}{r}0.327 \\
(0.322)\end{array}$ \\
\hline Nunes et al. (2009) & Portugal & 1999-2003 & Service sector & 75 & GMM & 2 & $\begin{array}{r}0.388 \\
(0.388)\end{array}$ \\
\hline Shehzad et al. (2009) & $\begin{array}{c}36 \\
\text { developing \& } \\
65 \text { non- } \\
\text { developing }\end{array}$ & $1997-2007$ & Banking & 1,522 & GMM & 9 & $\begin{array}{r}0.858 \\
(0.916)\end{array}$ \\
\hline Liu and Wilson (2010) & Japan & $2000-2007$ & Banking & 652 & GMM & 2 & $\begin{array}{r}0.092 \\
(0.092)\end{array}$ \\
\hline $\begin{array}{l}\text { Dietrich and Wanzenried } \\
\text { (2011) }\end{array}$ & Switzerland & 1999-2009 & Banking & 372 & GMM & 12 & $\begin{array}{r}0.112 \\
(0.108)\end{array}$ \\
\hline Goddard et al. (2011) & $\begin{array}{c}65 \\
\text { countries }\end{array}$ & $1997-2007$ & Banking & 8,570 & GMM & 65 & $\begin{array}{r}0.430 \\
(0.454)\end{array}$ \\
\hline Nakano and Kim (2011) & Japan & 1988-2007 & Manufacturing & 1,633 & GMM & 54 & $\begin{array}{r}0.148 \\
(0.183)\end{array}$ \\
\hline Saona Hoffmann (2011) & U.S. & $1995-2007$ & Banking & 11,777 & $\begin{array}{l}\text { GMM, fixed } \\
\text { effects \& } \\
\text { OLS }\end{array}$ & 9 & $\begin{array}{r}0.674 \\
(0.625)\end{array}$ \\
\hline Gschwandtner (2012) & U.S. & $\begin{array}{l}1950-1966 \\
1967-1983 \\
1984-1999\end{array}$ & Manufacturing & $\begin{array}{r}567 \\
980 \\
1,099\end{array}$ & GMM & 3 & $\begin{array}{r}0.645 \\
(0.664)\end{array}$ \\
\hline Alarcon and Sanchez (2013) & Spain & $2000-2008$ & Food industry & 341 & GMM & 2 & $\begin{array}{r}0.160 \\
(0.160)\end{array}$ \\
\hline Goddard et al. (2013) & 8 European & $1992-2007$ & Banking & 32,874 & GMM & 24 & $\begin{array}{r}0.325 \\
(0.322)\end{array}$ \\
\hline
\end{tabular}




\begin{tabular}{|c|c|c|c|c|c|c|c|}
\hline $\begin{array}{l}\text { Hirsch and Gschwandtner } \\
\text { (2013) }\end{array}$ & $\begin{array}{l}\text { Belgium } \\
\text { France } \\
\text { Italy } \\
\text { Spain } \\
\text { UK }\end{array}$ & $1996-2008$ & $\begin{array}{c}\text { Food } \\
\text { Manufacturing }\end{array}$ & $\begin{array}{r}841 \\
2,786 \\
596 \\
1,043 \\
228\end{array}$ & GMM & 5 & $\begin{array}{r}0.204 \\
(0.205)\end{array}$ \\
\hline Giotopoulos (2014) & Greece & 2004-2012 & Service sectors & 35,612 & GMM & 24 & $\begin{array}{r}0.142 \\
(0.185)\end{array}$ \\
\hline Hirsch and Hartmann (2014) & EU-5 & 1996-2008 & $\begin{array}{c}\text { Food } \\
\text { Manufacturing }\end{array}$ & 351 & GMM & 1 & $\begin{array}{r}0.173 \\
(0.173)\end{array}$ \\
\hline Matyjas (2014) & Poland & $2007-2010$ & $\begin{array}{l}\text { All but } \\
\text { financial }\end{array}$ & 387 & OLS & 1 & $\begin{array}{r}0.299 \\
(0.299)\end{array}$ \\
\hline Pattitoni et al. (2014) & EU-15 & 2004-2011 & All private & 30,764 & GMM & 1 & $\begin{array}{r}0.426 \\
(0.426)\end{array}$ \\
\hline Schmidt (2014) & U.S. & $2005-2013$ & $\begin{array}{l}\text { All publicly } \\
\text { quoted }\end{array}$ & 392 & OLS & 1 & $\begin{array}{r}0.921 \\
(0.921)\end{array}$ \\
\hline Amidu and Harvey (2015) & Africa & $2002-2009$ & Banking & 330 & GMM & 4 & $\begin{array}{r}0.554 \\
(0.550)\end{array}$ \\
\hline $\begin{array}{l}\text { Gschwandtner and Hirsch } \\
\text { (2015) }\end{array}$ & U.S. & $1990-2012$ & $\begin{array}{c}\text { Food } \\
\text { Manufacturing }\end{array}$ & 125 & $\begin{array}{l}\text { GMM \& } \\
\text { OLS }\end{array}$ & 3 & $\begin{array}{r}0.361 \\
(0.292)\end{array}$ \\
\hline Pervan et al. (2015) & Croatia & $2002-2010$ & Banking & n.a. & GMM & 1 & $\begin{array}{r}0.131 \\
(0.131)\end{array}$ \\
\hline Tsoulfidis et al. (2015) & Japan & 1974-2008 & Manufacturing & n.a. & OLS & 52 & $\begin{array}{r}0.688 \\
(0.743)\end{array}$ \\
\hline
\end{tabular}

Source: Own literature search

\section{Meta-regression data}

The profit persistence values $(\hat{\lambda})$ reported by the studies summarized in Table 1 will serve as the dependent variable in the MRA. According to Table 2 which summarizes the meta-data mean $\hat{\lambda}$ across the 36 studies and 413 observations is 0.407 . Thus, empirical evidence indicates that on average $6.7 \%$ of abnormal profits prevail 3 years after they emerge. This is a first indication that the literature provides evidence for a mediocre degree of persistence in abnormal profits.

As described below, the relationship between $\hat{\lambda}$-values and their standard errors will serve as an indicator for publication bias (Stanley, 2005; 2008). Besides the effect that publication bias has on heterogeneity in reported results we analyze the impact of factors related to the study design. Study characteristics that are expected to determine the variability of profit persistence across literature are summarized in the lower panel of Table 2.

Gschwandtner (2012) shows that profit persistence in the US manufacturing sector has steadily decreased during the last decades due to an increase in international competition. To identify whether this effect prevails across literature we first calculated a variable that captures for each $\hat{\lambda}$-value the mean year of the underlying sample. However, this mean year variable caused severe problems regarding multicollinearity in several MRA specifications. We therefore incorporated a dummy variable (Pre-2003) that identifies studies where the mean year of the analyzed sample is $<2003$. The threshold year 2003 was determined as the median value of the mean year variable. Table 2 reveals that $87.4 \%$ of the analyzed studies focus on a mean year before 2003. 
It can be expected that the longer the time span of the analyzed sample the better the competitive convergence process is captured. Hence, longer time spans likely lead to lower profit persistence values. The variable no. of years identifies the length of the time series dimension of the analyzed panel. It can be observed that studies on average focus on panels with a time series dimension of 15.4 years.

As regards country types the literature has particularly focused on differences between developing and developed economies. Glen et al. (2001) and Stephan and Tsapin (2008) argue that profit persistence is lower in emerging markets due to low entry costs, stronger economic growth and fewer governmental interventions. In contrast, Chacar and Vissa (2005) state that developing countries provide institutional environments that restrict competition hence leading to stronger profit persistence. The effect of country focus is incorporated by the variable developing country which identifies $\hat{\lambda}$ values for firms in developing and emerging economies. $10.7 \%$ of the persistence coefficients are estimated for firms in such countries.

While the bulk of studies focuses on entire manufacturing or service sectors two subsectors have attracted notice. As stability in the banking sector is of significant importance for the functioning of capital markets and the whole economy starting with Goddard et al. (2004a) several studies with a specific focus on the banking sector have emerged. Banking sectors differ from manufacturing industries with respect to asset structures implying that bank returns are not comparable with those in other sectors. Therefore, banks are usually analyzed separately from manufacturing firms (McGahan and Porter, 1997; 1999). The dummy bank sector identifies profit persistence results for bank enterprises and thus captures differences in $\hat{\lambda}^{\text {'s }}$ between banking and manufacturing/service sector firms. Table 2 reveals that $37.0 \%$ of the $\hat{\lambda}^{\text {'s }}$ refer to the banking sector. Another sector that has attracted notice is the food industry (e.g. Alarcon and Sanchez, 2013). Hirsch and Gschwandtner (2013) find for the EU food industry a low degree of profit persistence and conclude that this sector is characterized by extreme competition and market saturation. Moreover, there is hardly any other sector with a stronger imbalance of market power between the processing industry and retailers (Wijnands et al., 2007). The variable food sector identifies $\hat{\lambda}$-values that have been generated for food industry firms. It can be observed that $7.3 \%$ of persistence estimates relate to this industry. 
Table 2. Summary statistics of the profit persistence meta-data

\begin{tabular}{|c|c|c|c|}
\hline Variable label & Definition & Mean & $\begin{array}{l}\text { Standard } \\
\text { deviation }\end{array}$ \\
\hline \multicolumn{4}{|c|}{ Dependent Variable } \\
\hline $\begin{array}{l}\text { Profit persistence } \\
(\hat{\lambda})\end{array}$ & $\begin{array}{l}\text { Autoregressive persistence coefficient of abnormal } \\
\text { profits between } t \text { and } t-1\end{array}$ & 0.407 & 0.278 \\
\hline \multicolumn{4}{|l|}{ Precision } \\
\hline $\begin{array}{l}\text { Standard error } \\
\operatorname{se}(\hat{\lambda})\end{array}$ & Standard error of the persistence coefficient $\hat{\lambda}$ & 0.057 & 0.060 \\
\hline \multicolumn{4}{|c|}{ Study design characteristics } \\
\hline Pre-2003 & $\begin{array}{l}\text { Mean year of the analyzed time span before } 2003=1 \text {; } \\
\text { otherwise }=0\end{array}$ & 0.874 & 0.332 \\
\hline No. of years & Length of the analyzed time series dimension & 15.412 & 9.481 \\
\hline $\begin{array}{l}\text { Developing } \\
\text { country }\end{array}$ & $\begin{array}{l}\text { The persistence coefficient is estimated for firms in a } \\
\text { developing country }=1 \text {; otherwise }=0\end{array}$ & 0.107 & 0.309 \\
\hline Bank sector & $\begin{array}{l}\text { The persistence coefficient is estimated for firms } \\
\text { operating in the banking sector }=1 \text {; otherwise }=0\end{array}$ & 0.370 & 0.484 \\
\hline Food sector & $\begin{array}{l}\text { The persistence coefficient is estimated for firms } \\
\text { operating in the food sector }=1 \text {; otherwise }=0\end{array}$ & 0.073 & 0.260 \\
\hline OLS & The estimation is based on OLS $=1$; otherwise $=0$ & 0.220 & 0.415 \\
\hline GMM & $\begin{array}{l}\text { The estimation is based on GMM-difference or } \\
\text { GMM-system=1; otherwise }=0\end{array}$ & 0.751 & 0.433 \\
\hline Fixed effects & $\begin{array}{l}\text { The estimation is based on fixed effects }=1 \text {; } \\
\text { otherwise }=0\end{array}$ & 0.029 & 0.168 \\
\hline Public & $\begin{array}{l}\text { The analyzed sample comprises publicly quoted } \\
\text { firms only=1; otherwise }=0\end{array}$ & 0.073 & 0.260 \\
\hline Firm size & $\begin{array}{l}\text { The estimation includes an explanatory variable } \\
\text { related to the size of firms }=1 \text {; otherwise }=0\end{array}$ & 0.266 & 0.443 \\
\hline Financial risk & $\begin{array}{l}\text { The estimation includes an explanatory variable } \\
\text { related to the financial risk of firms }=1 \text {; otherwise }=0\end{array}$ & 0.295 & 0.457 \\
\hline Concentration & $\begin{array}{l}\text { The estimation includes an explanatory variable } \\
\text { related to concentration of the industry in which a } \\
\text { firm operates=1; otherwise }=0\end{array}$ & 0.167 & 0.373 \\
\hline Industry size & $\begin{array}{l}\text { The estimation includes an explanatory variable } \\
\text { related to the size of the industry in which a firm } \\
\text { operates=1; otherwise }=0\end{array}$ & 0.031 & 0.175 \\
\hline Other & $\begin{array}{l}\text { The estimation includes a set of further explanatory } \\
\text { variables related to the firm or industry in which a } \\
\text { firm operates=1; otherwise }=0\end{array}$ & 0.273 & 0.446 \\
\hline
\end{tabular}

Several econometric methods have been employed to estimate $\hat{\lambda}$. Baltagi (2008) shows that pooled OLS is not suitable to estimate autoregressive relationships such as the one specified by (2a) and (2b). It can be assumed that the error term of (2a) and (2b) is the sum of a time-invariant firm component $\eta_{i}$ and an observation specific error component $v_{i, t}$. This 
implies that an endogeneity bias in form of $\operatorname{cov}\left(\pi_{i, t-1} ; \eta_{i}\right) \neq 0$ is present which renders the OLS estimate of $\lambda$ inconsistent and upward biased. It can easily be shown that the fixed effects estimator is also biased and inconsistent when applied to AR processes (e.g. Baltagi 2008). Baltagi (2008) illustrates that Arellano and Bond's (1991) GMM estimator leads to consistent and unbiased $\hat{\lambda}$-values. To assess the misspecification bias caused by applying pooled OLS or fixed effects we use dummy variables (OLS, GMM, and fixed effects) that take value 1 if the study is based on the respective estimator. It has to be noted that the GMM approach can be subdivided into the GMM-system and GMM-difference estimator ${ }^{6}$. Arellano and Bover (1995) and Blundell and Bond (1998) point out that the GMM-system estimator outperforms the difference estimator when applied to samples with a short time series dimension. However, as a significant number of studies do not report which of the GMM estimators has been applied we do not further differentiate between GMM-system and GMMdifference in our analysis. Moreover, as the profit persistence literature is based on relatively long samples with an average time series dimension of 15.4 years significant differences in the results of GMM-difference and GMM-system should not prevail. 75.1\% of the included studies have generated their results based on the GMM-system or GMM-difference estimator while 22.0 and $2.9 \%$ are based on OLS and fixed effects, respectively.

To assess whether $\hat{\lambda}$-values are influenced by the size of the analyzed firms we include the variable public which captures whether the underlying sample only comprises publicly quoted and thus larger firms. $7.3 \%$ of $\hat{\lambda}$-values relate to samples with large publicly quoted firms while the remaining studies also include SMEs. It needs to be noted that only a few studies include micro-sized firms (e.g. Hirsch and Gschwandtner, 2013). ${ }^{7}$

$44.1 \%$ of the $\hat{\lambda}$-values refer to models without additional covariates (eq. (2a)) while the remaining $\hat{\lambda}$-estimates are generated based on models that simultaneously estimate the impact of structural characteristics such as firm size or industry concentration (eq. (2b)). A general pattern with firm- and industry-specific variables can be observed where the majority of studies includes firm size and financial risk as firm-level characteristics and concentration as well as industry size as structural industry variables. We therefore incorporate dummy variables which capture whether the estimation controls for those characteristics. Respective descriptive statistics are reported in Table 2. $27.3 \%$ of the studies include further explanatory variables, mainly related to firms`strategic behavior or resources. Examples are market share, firm age, export intensity, $R \& D$, or advertising expenditure. However, many of those variables are used in less than $1 \%$ of the 413 included estimations. It is thus not feasible to 
control for each of those variables. We therefore capture the inclusion of further explanatory variables by means of a single dummy variable other.

Some specifications are too particular to be controlled for within the MRA framework as they only appear in a single study. Goddard et al. (2013), for example, provide results for several subsamples of different bank types. Chacar and Vissa (2005) split their samples into poor and superior performers while Geroski et al. (1993) provide separate estimations for innovators and non-innovators. In those cases we only include the estimates that relate to the full sample of firms. Wang and Shailer (2015) note that it is important to control for the type of profitability measure used to estimate the effect (i.e. accounting versus market measures) ${ }^{8}$. However, all 413 included $\hat{\lambda}$-values have been generated using accounting measures while none of the values has been estimated based on market measures of performance.

\section{Meta-analysis framework}

In section 4.1 we conduct an initial analysis of the distribution of reported $\hat{\lambda}$-values to derive first insights regarding publication bias and the level of 'true' empirical profit persistence. Subsequently, we provide several MRA specifications that enable to determine the level of the 'true' empirical effect while simultaneously controlling for the presence of publication biases and the impact of study design characteristics.

\subsection{An initial analysis of publication bias}

To deduce an approximation for the 'true' persistence value and to provide first insights regarding the presence of publication bias we follow the procedures proposed by Stanley (2005).

Publication bias arises if statistically significant results are more likely to be published than non-significant ones. According to Stanley (2005; 2008) a precise indicator for publication bias is the relationship between reported estimates and their standard errors such as t-statistics that average around two across the literature of interest. A funnel plot, which graphs estimated coefficients and their precision, can serve to get a first impression of this relationship (Stanley and Doucouliagos, 2010). Precision is calculated for each estimate as the reciprocal of its standard error (Oczkowski and Doucouliagos, 2014; Zigraiova and Havranek, 2015). If publication bias is not present reported estimates should vary in form of a symmetrical inverted funnel around the ‘true' persistence value. Estimates with low precision are at the bottom of the plot and characterized by higher variation while more precise estimates at the top of the graph form the funnel's neck. Skewness of the funnel in either 
direction can be interpreted as evidence for publication bias. To derive a proxy for the 'true' level of persistence as suggested by Stanley (2005) we average the top $10 \%$ of $\hat{\lambda}$-values in our sample. This mean amounts to 0.381 .

Figure 1: Funnel plot for the profit persistence measure $(\hat{\lambda})$

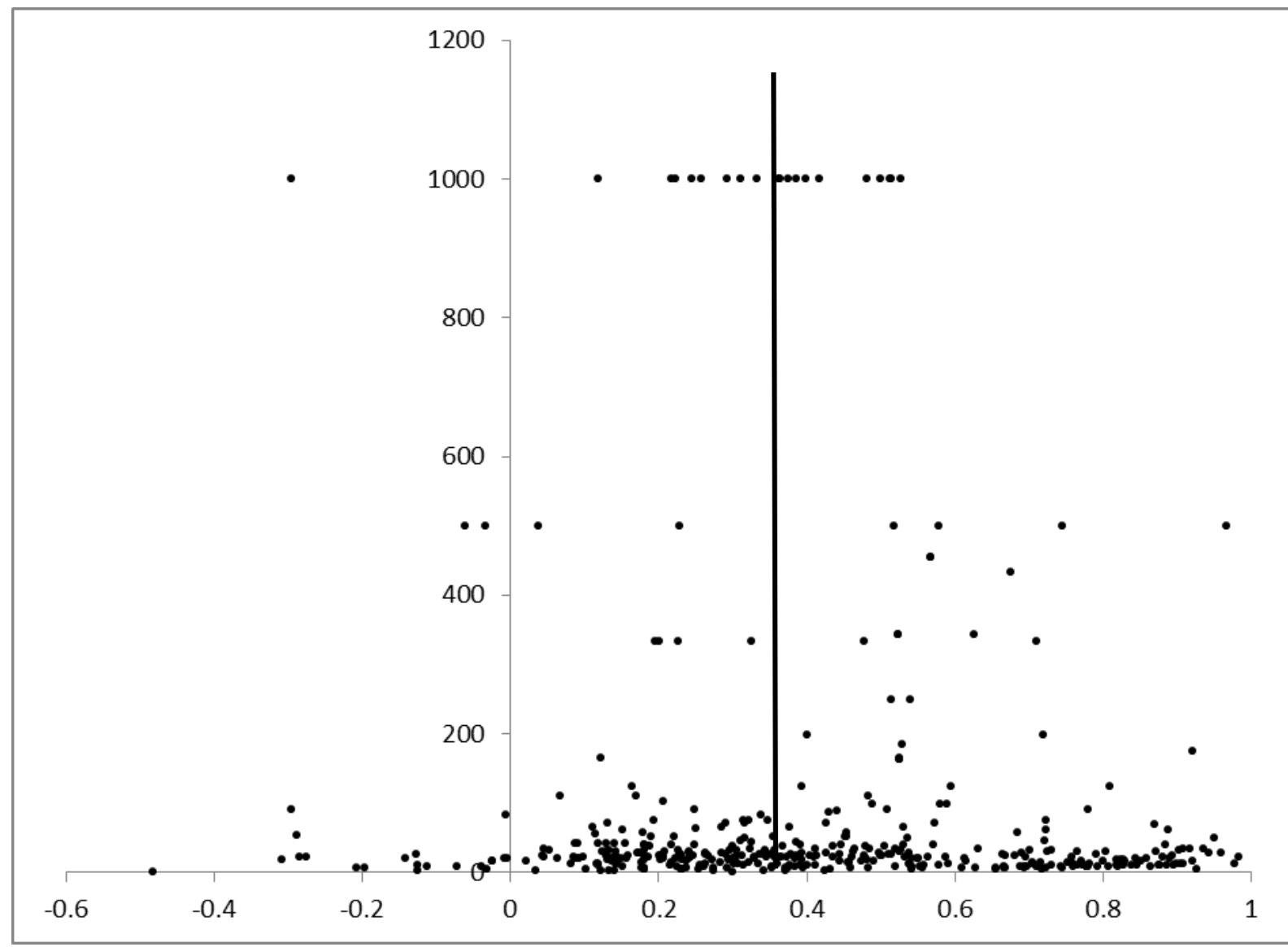

Note: The $\mathrm{x}$-axis measures profit persistence $(\hat{\lambda})$. The $\mathrm{y}$-axis represents precision measured by the reciprocal of the standard errors of the profit persistence measure. The vertical line indicates the proxy for 'true' profit persistence (0.381).

Figure 1 depicts the funnel plot for the profit persistence literature. The vertical line at 0.381 indicates the proxy for the 'true' persistence value. It can be observed that the funnel is overly widely spread across the entire range of precision. Such excess variation points towards a type of publication bias that favors significant results regardless of their direction. Regarding firm profit persistence both high $\hat{\lambda}$-values close to one as well as coefficients close to or below zero are supported by economic theory and thus meaningful outcomes. This implies that publication bias does not necessarily force authors to only report significant $\hat{\lambda}$ values in the interval $0<\hat{\lambda}<1$ as $-1<\hat{\lambda} \leq 0$ also constitutes a 'desirable' result. A straightforward method to assess the excess to which significant coefficients are reported is 
the following statistic: $\phi_{j}=\left|\left(\hat{\lambda}_{j}-\lambda\right) / \operatorname{se}\left(\hat{\lambda}_{j}\right)\right|$, where $\hat{\lambda}_{j}$ are the reported estimates, $\operatorname{se}\left(\hat{\lambda}_{j}\right)$ the respective standard errors, and $\lambda$ the underlying 'true' effect. If an abnormal tendency to report significant results prevails $\phi_{j}$ will exceed 1.96 for more than $5 \%$ of the observed estimates (Stanley, 2005). Under the assumption that the 'true' effect is $\lambda=0.381$ the $\phi_{j}$ statistic exceeds 1.96 for $75.5 \%$ of the reported persistence estimates hence strongly supporting the impression of excess variation provided by the funnel plot.

Although these results point towards a publication bias in both directions, the main drawback of the graphical analysis as well as of the $\phi_{j}$-statistic is the assumption of a single 'true' effect which holds for all studies regardless of the underlying study design. Nevertheless, if the 'true' effect is heterogeneous e.g. across countries, industries or time periods skewness or excess variation of the distribution can also be a result of the study focus or different estimation techniques and does not necessarily have to reflect publication bias. The MRA in the following section provides a more formal statistical test that can identify subareas of publication bias that the funnel graph cannot reveal (Doucouliagos et al., 2005; Stanley 2005, 2008). For the profit persistence literature this is of particular importance as three different types of 'desirable' $\hat{\lambda}$ results exist that can independently be subject to publication bias.

\subsection{Meta-regression model}

To provide a more objective assessment of publication bias than what the funnel-plot analysis can reveal and to explore the determinants of heterogeneity in reported profit persistence values we estimate several MRA specifications based on the following model (Stanley 2005, 2008):

$\hat{\lambda}_{j}=\beta_{0}+\beta_{1} \operatorname{se}\left(\hat{\lambda}_{j}\right)+\sum_{n} \beta_{n} x_{n j}+\varepsilon_{j}$

The dependent variable $\hat{\lambda}_{j}$ captures the $j=1, \ldots$, 413 profit persistence coefficients while $\operatorname{se}\left(\hat{\lambda}_{j}\right)$ represents the corresponding standard errors. $x_{n}$ are variables associated with the study design used to estimate $\hat{\lambda}_{j}$ (see lower part of Table 2). Inclusion of those variables helps to identify potential misspecification problems that prevail across literature. The $\beta_{n}$ capture variability in $\hat{\lambda}_{j}$ due to study design characteristics after controlling for publication bias. $\varepsilon_{j}$ is a classical i.i.d. error term. 
If publication bias is present, estimated effects $\left(\hat{\lambda}_{j}\right)$ will be correlated with their standard errors as researches favor results with a relationship between $\hat{\lambda}_{j}$ and $\operatorname{se}\left(\hat{\lambda}_{j}\right)$ that leads to an 'adequate' level of statistical significance (Oczkowski and Doucouliagos, 2014). In this case $\hat{\beta}_{1}$ will be different from zero. Without publication bias reported $\hat{\lambda}_{j}$-coefficients should vary randomly around the 'true' value and correlation between $\hat{\lambda}_{j}$ and $\operatorname{se}\left(\hat{\lambda}_{j}\right)$ should be insignificant. Testing $H_{0}: \hat{\beta}_{1}=0$ can hence be considered as a test for the presence of publication bias. As the test of $H_{0}$ is also a measure for the asymmetry of the funnel plot it is usually referred to as funnel asymmetry test (FAT) (Stanley, 2005; 2008).

The excess variation revealed by the funnel plot highlights the necessity to test for publication bias independent of direction. Moreover, the fact that three different types of 'desirable' results for $\hat{\lambda}$ exist implies that publication bias has to be analyzed separately for the positive and negative domain of $\hat{\lambda}_{j}$. If publication bias towards the existence of profit persistence is present a significant positive relationship between $\hat{\lambda}_{j}$ and $\operatorname{se}\left(\hat{\lambda}_{j}\right)$ should prevail for the interval $0<\hat{\lambda}_{j}<1$. In turn if publication bias towards instability of profits exists there should be a significant negative correlation between $\hat{\lambda}_{j}$ and $\operatorname{se}\left(\hat{\lambda}_{j}\right)$ over the interval $-1<\hat{\lambda}_{j}<0$. We address the issue of possible bi-directional publication bias by extending the estimation strategy of Kim et al. (2014) ${ }^{9}$. As a base model, we estimate the MRA model without additional study design covariates:

$\hat{\lambda}_{j}=\beta_{0}+\beta_{1} \operatorname{se}\left(\hat{\lambda}_{j}\right)+\varepsilon_{j}$

The 'true' empirical effect beyond publication bias is reflected by the intercept $\hat{\beta}_{0}$. Thus, testing $H_{0}: \hat{\beta}_{0}=0$ is a test for the existence of a 'true' empirical effect of profit persistence also referred to as precision effect test (PET) (Stanley, 2005; 2008).

We then estimate (4) by replacing $\operatorname{se}\left(\hat{\lambda}_{j}\right)$ with $\operatorname{se}\left(\hat{\lambda}_{j}\right)^{2}$ to consider a nonlinear relationship between $\hat{\lambda}_{j}$ and $s e\left(\hat{\lambda}_{j}\right)$ over the domain of $\hat{\lambda}_{j}$. This yields a more accurate estimate of the underlying effect and better identifies publication bias as it allows the latter to be less severe for more precise estimates (Bom and Ligthart, 2009; Stanley and Doucouliagos, 2012):

$\hat{\lambda}_{j}=\beta_{0}+\beta_{1} \operatorname{se}\left(\hat{\lambda}_{j}\right)^{2}+\varepsilon_{j}$ 
To more precisely investigate the presence of publication bias that is indifferent to the direction of the empirical effect we follow Stanley (2005) and estimate models (4) and (5) using the absolute value of reported coefficients as dependent variable:

$\left|\hat{\lambda}_{j}\right|=\beta_{0}+\beta_{1} \operatorname{se}\left(\hat{\lambda}_{j}\right)+\varepsilon_{j}$

$\left|\hat{\lambda}_{j}\right|=\beta_{0}+\beta_{1} \operatorname{se}\left(\hat{\lambda}_{j}\right)^{2}+\varepsilon_{j}$

This allows to capture publication bias independent of its direction.

However, when study design variables are added to the model $\left|\hat{\lambda}_{j}\right|$ cannot be used as a dependent variable. Thus, to account for different impacts of $\operatorname{se}\left(\hat{\lambda}_{j}\right)$ over the positive and the negative domain of $\hat{\lambda}$ under consideration of study design characteristics, interactions of dummy variables with $s e\left(\hat{\lambda}_{j}\right)$ are added (Bom and Lingthart, 2009);

$\hat{\lambda}_{j}=\beta_{0}+\beta_{2} D_{1} \operatorname{se}\left(\hat{\lambda}_{j}\right)+\beta_{3} D_{2} \operatorname{se}\left(\hat{\lambda}_{j}\right)+\sum_{n} \beta_{n} x_{n j}+\varepsilon_{j}$

with $D_{1}=\left\{\begin{array}{ll}1 & \text { if } 0<\hat{\lambda}_{j}<1 \\ 0 & \text { otherwise }\end{array}\right.$ and $\quad D_{2}= \begin{cases}1 & \text { if }-1<\hat{\lambda}_{j}<0 \\ 0 & \text { otherwise }\end{cases}$

$H_{1}: \hat{\beta}_{2}=0$ is now the test for publication bias towards profit persistence and we expect that $\hat{\beta}_{2}$ is significantly larger than zero if this kind of bias prevails. Similarly, $H_{2}: \hat{\beta}_{3}=0$ is the test for publication bias in the direction of profit instability. It can be expected that $H_{2}$ is rejected for $\hat{\beta}_{3}<0$ if bias towards profit instability is present. ${ }^{10}$

In addition to using interaction terms we also account for a more flexible relationship between $\hat{\lambda}_{j}$ and $s e\left(\hat{\lambda}_{j}\right)$ over the domain of $\hat{\lambda}_{j}$ by incorporating the standard error in a nonlinear fashion (Bom and Ligthart, 2009; Stanley and Doucouliagos, 2012):

$\hat{\lambda}_{j}=\beta_{0}+\beta_{4} \operatorname{se}\left(\hat{\lambda}_{j}\right)^{2}+\sum_{n} \beta_{n} x_{n j}+\varepsilon_{j}$

$H_{3}: \hat{\beta}_{4}=0$ is now the respective test for publication bias.

In models (8) and (9) the intercept $\hat{\beta}_{0}$ represents the 'true' empirical effect beyond publication bias if all variables related to the underlying study design are zero (Doucouliagos and Stanley, 2009).

The estimation of the MRA models (4) to (9) involves several econometric hurdles. First, the dependent variable consists of estimated coefficients with non-homogeneous variances leading to heteroscedastic error terms (Nelson and Kennedy, 2009). However, as 
$\operatorname{se}\left(\hat{\lambda}_{j}\right)$ is a measure for this heteroscedasticity weighted least squares (WLS) with $1 / \operatorname{se}\left(\hat{\lambda}_{j}\right)^{2}$ as "optimal weights" can be used to generate corrected standard errors (Hedges and Olkin, 1985; Stanley, 2005; Oczkowski and Doucouliagos, 2014). Second, as our sample includes clusters of estimates from the same authors (29) or studies (36) the problem of correlated error structures within these clusters arises. Within-cluster correlation renders the MRA standard error estimates biased (Nelson and Kennedy, 2009). We therefore estimate the MRA models using WLS combined with several approaches to account for author and study related dependence of standard errors. Similar to Oczkowski and Doucouliagos (2014) we employ standard heteroscedasticity robust, cluster robust ${ }^{11}$ and wild bootstrapped clustered standard errors to account for nonzero correlation between the errors of estimates from the same author or study. We employ the wild cluster bootstrap method which is the adequate bootstrap approach when the number of clusters is small (Cameron et al., 2008). In addition, clusters in our dataset are of significantly different sizes. MacKinnon and Webb (2016) show that in this case the wild bootstrap may yield reliable inferences.

Several MRA studies have employed panel estimators to account for within author or study error dependence (Oczkowski and Doucouliagos, 2014). However, Stanley and Doucouliagos (2013) show that conventional random- and fixed estimators are outperformed by WLS due to lower bias and mean squared error if publication bias exists. Moreover, the random effects estimator is based on the adverse assumption that the random effect needs to be uncorrelated with the explanatory variables in order to obtain unbiased MRA coefficients (Baltagi, 2008; Stanley and Doucouliagos, 2013). In contrast, the fixed effects estimator allows for correlation between explanatory variables and the fixed effects. However, the inclusion of study specific fixed effects consumes a large number of degrees of freedom leading to inefficient estimates (Baltagi, 2008; Nelson and Kennedy, 2009). Moreover, the application of the fixed effects estimator to panels that comprise many small observation clusters, such as the present one, is doubtful (Nelson and Kennedy, 2009). ${ }^{12}$ Given its superiority we will focus on the estimation based on WLS. Nevertheless, as recommended by the MRA guidelines of Stanley et al. (2013) we will also apply panel estimators as sensitivity analysis and robustness checks of the WLS results.

\subsection{Meta-regression results}

Table 3 provides estimation results for the MRA models without study design covariates (eq. (4) to (7)). For reasons of clarity we only focus on the results using WLS with robust standard errors. Moreover, applying cluster robust and bootstrapped clustered standard errors does not 
change significances. ${ }^{13}$ The results confirm the excess variation revealed by the funnel plot (Figure 1). Columns (1) and (2) reveal the presence of net positive publication selection while columns (3) to (5) clearly reveal the existence of bi-directional publication bias. The constant term which serves as a measure for the 'true' persistence value corrected for publication bias -but without accounting for study design characteristics- ranges between 0.334 and 0.372 . Those values are statistically different from zero in all cases thus suggesting the rejection of the competitive environment hypothesis in favor for a mediocre degree of profit persistence.

Table 3. Profit persistence FAT-PET meta-regression analysis results

\begin{tabular}{|c|c|c|c|c|c|}
\hline \multirow[b]{2}{*}{ Variable } & \multicolumn{5}{|c|}{ Dependent Variable } \\
\hline & $\begin{array}{l}\hat{\lambda} \\
(1)\end{array}$ & $\begin{array}{l}\hat{\lambda} \\
(2) \\
\end{array}$ & $\begin{array}{l}|\hat{\lambda}| \\
(3)\end{array}$ & $\begin{array}{l}|\hat{\lambda}| \\
\text { (4) }\end{array}$ & $\begin{array}{l}\hat{\lambda} \\
\text { (5) }\end{array}$ \\
\hline Constant & $0.334(0.04)^{* * *}$ & $0.345(0.04)^{* * *}$ & $0.367(0.02)^{* * *}$ & $0.372(0.02)^{* * *}$ & $0.340(0.04)^{* * *}$ \\
\hline SE & $3.382(1.69)^{* *}$ & & $2.717(1.15)^{* *}$ & & \\
\hline $\mathrm{SE}^{2}$ & & $9.143(5.41)^{*}$ & & $7.803(3.74)^{* *}$ & \\
\hline $\mathrm{SE}^{*} D(\lambda>0)$ & & & & & $6.809(2.780)^{* *}$ \\
\hline $\mathrm{SE}^{*} D(\lambda<0)$ & & & & & $-52.782(24.754) * *$ \\
\hline $\mathrm{R}^{2}$ & 0.004 & 0.001 & 0.004 & 0.001 & 0.079 \\
\hline Adj. $R^{2}$ & 0.001 & 0.000 & 0.002 & 0.000 & 0.075 \\
\hline
\end{tabular}

Notes: Standard errors in parentheses; $* * *, * *, *$ significance at the $1,5,10 \%$ level

Results for MRA models with study design covariates (eq. (3), (8), and (9)) using WLS in combination with robust, cluster robust and wild bootstrapped clustered standard errors are reported in Table 4. Column (1) presents results for the standard MRA FAT-PET model (eq. (3)) where the standard error is introduced in a linear way. The results indicate the presence of net positive publication selection. Concerning study design characteristics the outcomes are similar to our preferred results discussed below -WLS with cluster robust standard errors. Columns (2) to (13) present results for the MRA models defined by equations (8) and (9). The constant ( $\hat{\beta}_{0}$ ) ranges between 0.497 for MRA models based on equation (8) and 0.547 for models based on equation (9). Those values are significant for all models presented in Table 4 and suggest a mediocre degree of profit persistence. The baseline model results - WLS with heteroscedasticity robust standard errors - reported in columns 2 and 3 reveal that publication bias is present when study design characteristics are considered. The positive and significant impact of the squared standard error in column (2) provides evidence for a net positive publication bias. Moreover, the significant interaction terms $D_{1} \operatorname{se}\left(\hat{\lambda}_{j}\right)$ and $D_{2} s e\left(\hat{\lambda}_{j}\right)$ in column (3) indicate the presence of publication bias both in the direction of 
persistence and instability of abnormal profits. However, it has to be kept in mind that standard errors of those results are not adjusted for clustered error structures. When using cluster robust standard errors that account for author related correlation (columns (4) and (5)) the results only provide hints towards publication bias which favors profit persistence. The results in columns (6) and (7) are corrected for study related error correlation and confirm the presence of positive publication selection. However, most of the studies that are provided by the same author are based on the same dataset which indicates that author clusters are more dominant than study clusters. ${ }^{14}$ Our preferred results are therefore those which account for author related correlation (columns (4) and (5)).

Several explanatory variables that reflect study design characteristics turn out to be significant drivers of variability in reported $\hat{\lambda}$-values. The pre-2003 dummy is positive and significant when author- and study cluster robust standard errors are used. The respective estimates indicate that focusing on firm samples with a mean year before 2003 increases profit persistence by a value of 0.067 to 0.068 . Hence, the suggested increase in international competition during the last decades, which has led to lower profit persistence (e.g. Gschwandtner, 2012) is reflected by the underlying literature.

The utilization of samples with longer time series dimensions has a negative impact on produced profit persistence values in all models with author- and study cluster robust standard errors. Longer time spans better reflect the convergence process of abnormal profits and therefore produce lower profit persistence values leading to the significant and negative no. of years variable.

In a number of studies (e.g. Glen et al., 2001; Stephan and Tsapin, 2008) the supposition is made that profit persistence is lower in developing economies due to less strict governmental regulations and stronger economic growth. However, it tends to be the case that developing countries constitute economic environments that promote profit persistence (e.g. Chacar and Vissa, 2005). This is undermined by the significant and positive effect of the developing country dummy in all WLS cluster robust specifications.

Several authors (e.g. Levonian, 1994; Goddard et al., 2004a) show that bank profits converge to the competitive norm more slowly than profits in manufacturing sectors and are hence more persistent. However, our results reveal that this is not in general the case as the bank sector dummy is insignificant across all MRA estimations. A similar result is found for the food industry. Many studies (e.g. Hirsch and Gschwandtner, 2013; Hirsch and Hartmann, 2014) find that profit persistence is low in the food industry due to saturated and highly competitive market structures as well as strong retailer market power. Nonetheless, this effect 
cannot be supported in the present case as the food sector variable is consistently insignificant.

The significant and negative coefficient of the GMM as well as the fixed effects dummy across all models with cluster robust standard errors clearly reveals the upward bias associated with estimating $\hat{\lambda}$ by means of OLS (which serves as the base group) (Baltagi, 2008). The effect of using GMM instead of OLS turns out as large as it leads to a decrease in profit persistence between 0.376 and 0.377 .

A sample selection bias associated with the restriction of the analyzed sample to large publicly quoted firms cannot be detected when cluster robust standard errors are used. Usually a positive impact of firm size on profit persistence ascribed to a simple cost-scale effect should be expected (Hirsch and Hartmann, 2014; Ollinger et al., 2000). Moreover, Hirsch and Gschwandtner (2013) find that particularly in manufacturing sectors that suffer from high bargaining power of retailers, such as the food industry, firm size is a crucial factor to prevail in competition. Beyond that, larger firms tend to be less effected by administrative burdens such as market approval processes or the handling of legal issues (Wijnands et al., 2007). Although the effect of the public dummy is mainly positive it is not significant in the WLS models with cluster corrected standard errors. However, it needs to be pointed out that several authors (e.g. Goddard et al., 2005) suggest that firm size can negatively influence profit persistence through inefficiency and diseconomies of scale. It is hence possible that both effects compensate each other leading to the insignificant impact of the public dummy.

As regards additional explanatory variables we find that the inclusion of firm size and financial risk measures significantly influences the generated persistence values. In contrast, controlling for industry structure with variables related to concentration and industry size has no impact on reported $\hat{\lambda}$ values. This result is in line with previous research on firm profitability which provides evidence for a predominance of firm related factors relative to industry structure as drivers of profitability and profit persistence (e.g. McGahan and Porter, 1997; Goddard et al., 2009; Chaddad and Mondelli, 2013). Accordingly the impact of the others dummy - which mainly refers to firm related factors - significantly impacts on reported $\hat{\lambda}$-values.

Columns (8) to (11) contain results with wild cluster bootstrapped standard errors clustered by author and study. Besides the variation that the fixed effects dummy has no significant impact those results mainly confirm the outcomes with cluster robust standard errors. 
Table 4. WLS results of meta-regression models under consideration of study design characteristics

\begin{tabular}{|c|c|c|c|c|c|c|c|}
\hline Variable & $\begin{array}{c}\text { Cluster } \\
\text { robust se } \\
\text { by author } \\
(1)\end{array}$ & $\begin{array}{c}\text { Robust se } \\
\text { (2) } \\
\end{array}$ & $\begin{array}{c}\text { Robust se } \\
\text { (3) } \\
\end{array}$ & $\begin{array}{c}\text { Cluster } \\
\text { robust se } \\
\text { by author } \\
(4)\end{array}$ & $\begin{array}{c}\text { Cluster } \\
\text { robust se } \\
\text { by author } \\
(5)\end{array}$ & $\begin{array}{c}\text { Cluster } \\
\text { robust se } \\
\text { by study } \\
(6) \\
\end{array}$ & $\begin{array}{c}\text { Cluster } \\
\text { robust se } \\
\text { by study } \\
(7)\end{array}$ \\
\hline \multirow[t]{2}{*}{ Constant } & 0.441 & 0.547 & 0.497 & 0.547 & 0.497 & 0.547 & 0.497 \\
\hline & $(0.07)^{* * *}$ & $(0.09)^{* * *}$ & $(0.10)^{* * *}$ & $(0.08) * * *$ & $(0.08)^{* * *}$ & $(0.08)^{* * *}$ & $(0.08) * * *$ \\
\hline SE & $\begin{array}{r}4.932 \\
(1.45)^{* * *}\end{array}$ & & & & & & \\
\hline \multirow[t]{2}{*}{$\mathrm{SE}^{*} D(\lambda>0)$} & & & 6.568 & & 6.568 & & 6.568 \\
\hline & & & $(2.81) * *$ & & $(2.05) * * *$ & & $(3.00)^{* *}$ \\
\hline $\mathrm{SE}^{*} D(\lambda<0)$ & & & $\begin{array}{r}-37.372 \\
(14.96)^{* *}\end{array}$ & & $\begin{array}{r}-37.372 \\
(32.59)\end{array}$ & & $\begin{array}{r}-37.372 \\
(34.24)\end{array}$ \\
\hline \multirow[t]{2}{*}{$\mathrm{SE}^{2}$} & & 13.132 & & 13.132 & & 13.132 & \\
\hline & & $(5.83) * *$ & & $(6.49) *$ & & $(7.71)^{*}$ & \\
\hline \multirow[t]{2}{*}{ Pre 2003} & 0.067 & 0.068 & 0.067 & 0.068 & 0.067 & 0.068 & 0.067 \\
\hline & $(0.00)^{* * *}$ & $(0.06)$ & $(0.06)$ & $(0.00) * * *$ & $(0.00)^{* * *}$ & $(0.00)^{* * *}$ & $(0.00) * * *$ \\
\hline \multirow[t]{2}{*}{ No. of years } & -0.003 & -0.003 & -0.003 & -0.003 & -0.003 & -0.003 & -0.003 \\
\hline & $(0.00)^{* * *}$ & $(0.01)$ & $(0.01)$ & $(0.00) * * *$ & $(0.00)^{* * *}$ & $(0.00)^{* * *}$ & $(0.00) * * *$ \\
\hline \multirow[t]{2}{*}{ Developing country } & 0.338 & 0.338 & 0.321 & 0.338 & 0.321 & 0.338 & 0.321 \\
\hline & $(0.01)^{* * *}$ & $(0.178)^{*}$ & $(0.17)^{*}$ & $(0.01)^{* * *}$ & $(0.01)^{* * *}$ & $(0.01)^{* * *}$ & $(0.01)^{* * *}$ \\
\hline \multirow[t]{2}{*}{ Bank sector } & 0.030 & -0.080 & -0.020 & -0.080 & -0.020 & -0.080 & -0.020 \\
\hline & $(0.08)$ & $(0.14)$ & $(0.10)$ & $(0.09)$ & $(0.09)$ & $(0.09)$ & $(0.08)$ \\
\hline \multirow[t]{2}{*}{ Food sector } & -0.000 & 0.005 & 0.031 & 0.005 & 0.031 & 0.005 & 0.031 \\
\hline & $(0.08)$ & $(0.10)$ & $(0.12)$ & $(0.10)$ & $(0.10)$ & $(0.09)$ & $(0.10)$ \\
\hline \multirow[t]{2}{*}{ GMM } & -0.389 & -0.377 & -0.376 & -0.377 & -0.376 & -0.377 & -0.376 \\
\hline & $(0.03)^{* * *}$ & $(0.06)^{* * *}$ & $(0.06)^{* * *}$ & $(0.03) * * *$ & $(0.03)^{* * *}$ & $(0.03)^{* * *}$ & $(0.03) * * *$ \\
\hline \multirow[t]{2}{*}{ Fixed effects } & -0.123 & -0.129 & -0.124 & -0.129 & -0.124 & -0.129 & -0.124 \\
\hline & $(0.04)^{* * *}$ & $(0.04)^{* * *}$ & $(0.03)^{* * *}$ & $(0.05)^{* *}$ & $(0.04)^{* * *}$ & $(0.05)^{* *}$ & $(0.04)^{* * *}$ \\
\hline \multirow[t]{2}{*}{ Public } & 0.191 & 0.101 & 0.132 & 0.101 & 0.132 & 0.101 & 0.132 \\
\hline & $(0.08)^{* *}$ & $(0.08)$ & $(0.08)^{*}$ & (0.09) & $(0.09)$ & $(0.09)$ & $(0.08)$ \\
\hline \multirow[t]{2}{*}{ Firm size } & 0.061 & 0.073 & 0.056 & 0.073 & 0.056 & 0.073 & 0.056 \\
\hline & $(0.03)^{*}$ & $(0.05)$ & $(0.05)$ & $(0.04)^{*}$ & $(0.03)^{*}$ & $(0.04)^{*}$ & $(0.03)^{*}$ \\
\hline \multirow[t]{2}{*}{ Financial risk } & -0.202 & -0.200 & -0.200 & -0.200 & -0.200 & -0.200 & -0.200 \\
\hline & $(0.00)^{* * *}$ & $(0.04)^{* * *}$ & $(0.04)^{* * *}$ & $(0.01)^{* * *}$ & $(0.01)^{* * *}$ & $(0.01)^{* * *}$ & $(0.01)^{* * *}$ \\
\hline \multirow[t]{2}{*}{ Concentration } & 0.042 & 0.028 & 0.032 & 0.028 & 0.032 & 0.028 & 0.032 \\
\hline & $(0.03)$ & $(0.06)$ & $(0.06)$ & $(0.03)$ & $(0.03)$ & $(0.03)$ & (0.03) \\
\hline \multirow[t]{2}{*}{ Industry size } & 0.132 & 0.109 & 0.045 & 0.109 & 0.045 & 0.109 & 0.045 \\
\hline & $(0.09)$ & $(0.10)$ & $(0.12)$ & $(0.12)$ & $(0.13)$ & $(0.12)$ & $(0.12)$ \\
\hline \multirow[t]{2}{*}{ Other } & 0.219 & 0.230 & 0.207 & 0.230 & 0.207 & 0.230 & 0.207 \\
\hline & $(0.03)^{* * *}$ & $(0.13)^{*}$ & $(0.11)^{*}$ & $(0.03)^{* * *}$ & $(0.03)^{* * *}$ & $(0.03)^{* * *}$ & $(0.03)^{* * *}$ \\
\hline $\mathrm{F}$ & 5401.19 & 132.65 & 132.29 & 4166.22 & 5341.25 & 3973.26 & 2885.56 \\
\hline$p(F)$ & 0.000 & 0.000 & 0.000 & 0.000 & 0.000 & 0.000 & 0.000 \\
\hline \multicolumn{8}{|l|}{ Wald $\chi$} \\
\hline \multicolumn{8}{|l|}{$\mathrm{p}(\chi)$} \\
\hline $\mathrm{R}^{2}$ & 0.364 & 0.360 & 0.403 & 0.360 & 0.403 & 0.360 & 0.403 \\
\hline Adj. $R^{2}$ & 0.341 & 0.337 & 0.380 & 0.337 & 0.380 & 0.337 & 0.380 \\
\hline
\end{tabular}


Table 4 (cont.). WLS results of meta-regression models under consideration of study design characteristics

\begin{tabular}{|c|c|c|c|c|c|c|}
\hline Variable & $\begin{array}{c}\text { Wild } \\
\text { Bootstrap se } \\
\text { clustered by } \\
\text { author } \\
\text { (8) }\end{array}$ & $\begin{array}{c}\text { Wild } \\
\text { Bootstrap } \\
\text { se clustered } \\
\text { by author } \\
\text { (9) }\end{array}$ & $\begin{array}{c}\text { Wild } \\
\text { Bootstrap } \\
\text { se clustered } \\
\text { by study } \\
\text { (10) }\end{array}$ & $\begin{array}{c}\text { Wild } \\
\text { Bootstrap } \\
\text { se clustered } \\
\text { by study } \\
\text { (11) }\end{array}$ & $\begin{array}{c}\text { Random } \\
\text { effects by } \\
\text { author, } \\
\text { WLS } \\
\text { (12) }\end{array}$ & $\begin{array}{c}\text { Random } \\
\text { effects by } \\
\text { author, } \\
\text { WLS } \\
\text { (13) }\end{array}$ \\
\hline \multirow[t]{2}{*}{ Constant } & 0.547 & 0.497 & 0.547 & 0.497 & 0.547 & 0.497 \\
\hline & {$[0.000]^{* * *}$} & {$[0.000]^{* * *}$} & {$[0.000]^{* * *}$} & {$[0.000]^{* * *}$} & $(0.13) * * *$ & $(0.14) * * *$ \\
\hline \multirow[t]{2}{*}{$\mathrm{SE}^{*} D(\lambda>0)$} & & 6.568 & & 6.568 & & 6.568 \\
\hline & & [0.102] & & [0.154] & & $(2.86)^{* *}$ \\
\hline \multirow[t]{2}{*}{$\mathrm{SE}^{*} D(\lambda<0)$} & & -37.372 & & -37.372 & & -37.372 \\
\hline & & [0.462] & & {$[0.558]$} & & $(8.65) * * *$ \\
\hline \multirow[t]{2}{*}{$\mathrm{SE}^{2}$} & 13.132 & & 13.132 & & 13.132 & \\
\hline & {$[0.100]^{*}$} & & [0.154] & & (26.19) & \\
\hline \multirow[t]{2}{*}{ Pre 2003} & 0.068 & 0.067 & 0.068 & 0.067 & 0.068 & 0.067 \\
\hline & {$[0.000]^{* * *}$} & {$[0.000]^{* * *}$} & {$[0.000]^{* * *}$} & {$[0.000]^{* * *}$} & $(0.02) * * *$ & $(0.02) * * *$ \\
\hline \multirow[t]{2}{*}{ No. of years } & -0.003 & -0.003 & -0.003 & -0.003 & -0.003 & -0.003 \\
\hline & {$[0.002]^{* * *}$} & {$[0.002]^{* * *}$} & {$[0.002]^{* * *}$} & {$[0.002]^{* * *}$} & $(0.00)$ & $(0.00)$ \\
\hline \multirow[t]{2}{*}{ Developing country } & 0.338 & 0.321 & 0.338 & 0.321 & 0.338 & 0.321 \\
\hline & {$[0.000]^{* * *}$} & {$[0.000]^{* * *}$} & {$[0.000]^{* * *}$} & {$[0.000]^{* * *}$} & $(0.03)^{* * *}$ & $(0.03)^{* * *}$ \\
\hline \multirow[t]{2}{*}{ Bank sector } & -0.080 & -0.020 & -0.080 & -0.020 & -0.080 & -0.020 \\
\hline & {$[0.508]$} & [0.872] & {$[0.478]$} & [0.846] & $(0.11)$ & $(0.12)$ \\
\hline \multirow[t]{2}{*}{ Food sector } & 0.005 & 0.031 & 0.005 & 0.031 & 0.005 & 0.031 \\
\hline & [0.964] & [0.822] & [0.948] & {$[0.786]$} & $(0.36)$ & $(0.35)$ \\
\hline \multirow[t]{2}{*}{ GMM } & -0.377 & -0.376 & -0.377 & -0.376 & -0.377 & -0.376 \\
\hline & {$[0.002]^{* * *}$} & {$[0.002]^{* * *}$} & {$[0.002]^{* * *}$} & {$[0.002]^{* * *}$} & $(0.07)^{* * *}$ & $(0.07) * * *$ \\
\hline \multirow[t]{2}{*}{ Fixed effects } & -0.129 & -0.124 & -0.129 & -0.124 & -0.129 & -0.124 \\
\hline & [0.444] & [0.114] & {$[0.420]$} & [0.104] & $(0.07)^{*}$ & $(0.07)^{*}$ \\
\hline \multirow[t]{2}{*}{ Public } & 0.101 & 0.132 & 0.101 & 0.132 & 0.101 & 0.132 \\
\hline & [0.338] & [0.214] & {$[0.292]$} & [0.114] & $(0.13)$ & (0.13) \\
\hline \multirow[t]{2}{*}{ Firm size } & 0.073 & 0.056 & 0.073 & 0.056 & 0.073 & 0.056 \\
\hline & {$[0.222]$} & {$[0.060]^{*}$} & [0.308] & {$[0.126]$} & $(0.08)$ & $(0.08)$ \\
\hline \multirow[t]{2}{*}{ Financial risk } & -0.200 & -0.200 & -0.200 & -0.200 & -0.200 & -0.200 \\
\hline & {$[0.002]^{* * *}$} & {$[0.002]^{* * *}$} & {$[0.002]^{* * *}$} & {$[0.002]^{* * *}$} & $(0.04) * * *$ & $(0.04) * * *$ \\
\hline \multirow[t]{2}{*}{ Concentration } & 0.028 & 0.032 & 0.028 & 0.032 & 0.028 & 0.032 \\
\hline & {$[0.478]$} & [0.382] & {$[0.450]$} & {$[0.362]$} & $(0.07)$ & $(0.07)$ \\
\hline \multirow[t]{2}{*}{ Industry size } & 0.109 & 0.045 & 0.109 & 0.045 & 0.109 & 0.045 \\
\hline & [0.536] & [0.792] & [0.526] & [0.786] & $(0.35)$ & $(0.34)$ \\
\hline \multirow[t]{2}{*}{ Other } & 0.230 & 0.207 & 0.230 & 0.207 & 0.230 & 0.207 \\
\hline & {$[0.000]^{* * *}$} & {$[0.000]^{* * *}$} & {$[0.000]^{* * *}$} & {$[0.000]^{* * *}$} & $(0.07)^{* * *}$ & $(0.07)^{* * *}$ \\
\hline \multicolumn{7}{|l|}{$\mathrm{F}$} \\
\hline \multicolumn{7}{|l|}{$\mathrm{p}(\mathrm{F})$} \\
\hline Wald $\chi$ & & & & & 1982.37 & 2155.99 \\
\hline $\mathrm{p}(\chi)$ & & & & & 0.000 & 0.000 \\
\hline \multicolumn{7}{|l|}{$\mathrm{R}^{2}$} \\
\hline Adj. $R^{2}$ & & & & & & \\
\hline
\end{tabular}

Notes: dependent variable is profit persistence $\hat{\lambda}_{j}$; standard errors in parentheses; p-values in brackets; $* * * * *, *$ significance at the 1,5 , $10 \%$ level; $D(\lambda>0)$ denotes a dummy variable with value 1 if the dependent variable $\hat{\lambda}_{j}$ is $>0$ and zero otherwise; $D(\lambda<0)$ denotes a dummy variable with value 1 if the dependent variable $\hat{\lambda}_{j}$ is $<0$ and zero otherwise;

Table 4 also provides panel estimator results for MRA models (8) and (9) that shall serve as robustness and sensitivity analysis of the WLS results. We focus on the weighted random effects estimator under consideration of observation grouping by author. Fixed effects results are neglected as the efficiency of the random effects estimator is confirmed by Hausman-specification tests. The weighted random effects estimator supports the presence of 
bi-directional publication bias. Regarding study design characteristics this estimator approximately reflects the results with cluster corrected standard errors indicating some degree of robustness. Only exception is the no. of years variable which turns out as insignificant in this case. While the application of the random effects estimator can serve to highlight differences in the results due to different estimation approaches it has to be kept in mind that it does not constitute the adequate approach to address the econometric hurdles involved with the estimation of MRA models (8) and (9) (Stanley and Doucouliagos, 2013).

Regarding model diagnostics F-tests as well as Wald tests (for panel estimators) indicate the overall significance of all models. Variance Inflation Factors reveal that none of the models is plagued by multicollinearity. The adjusted $\mathrm{R}^{2}$ values show that up to $38.0 \%$ of the variation in reported $\hat{\lambda}$ values can be attributed to publication selection and study design characteristics.

\section{Discussion and implications}

The main findings of the meta-analysis of 36 profit persistence studies conducted over the last three decades reveal a mediocre degree of persistence in abnormal firm profits. Averaging the top $10 \%$ of the 413 included profit persistence coefficients regarding precision yields a proxy for the true profit persistence value of 0.381 . An initial graphical analysis of the heterogeneity in reported $\hat{\lambda}$-values reveals strong excess variation around the proxy for 'true' persistence which points towards publication bias independent of direction. However, the drawback of this approach lies in the assumption that a single 'true' effect exists regardless of the underlying study design. The MRA can serve to model those impacts while simultaneously controlling for the presence of publication bias. Similar to Stanley and Doucouliagos (2013) as well as Oczkowski and Doucouliagos (2014) we focus on WLS with error-cluster corrected standard errors as the adequate MRA estimation approach. We find that the variation in reported estimates is influenced by publication bias in favor for research that supports the existence of profit persistence. Hence there is a tendency that authors of primary studies retain results that point towards fast erosion of abnormal profits and thus high competition.

Moreover, the MRA results reveal the importance of several characteristics related to the design and implementation of profit persistence studies. We find that a number of variables that capture the study design significantly impact on reported $\hat{\lambda}$-values. Setting all explanatory variables related to the underlying study design equal to zero the results indicate that after controlling for publication bias a mediocre but significant degree of profit 
persistence between 0.497 and 0.547 is present. Analyzing samples with a mean year of focus before 2003 increases those profit persistence values by 0.067 to 0.068 , highlighting an overall increase in international competition in the last decades. In turn a focus on developing countries increases profit persistence by a value of 0.321 to 0.338 likely due to less competitive economic environments in those countries. In contrast, a significant impact of focus on the banking sector or the food industry cannot be detected. For future profit persistence studies those findings imply that it is of particular importance to interpret results and derive implications in due consideration of the underlying study focus. This holds particularly when comparing results of studies with a different country, or time focus. As regards technical study characteristics it appears particularly important to employ the GMM estimator as the adequate econometric technique. The results indicate that applying GMM instead of OLS decreases estimated $\hat{\lambda}$-values by 0.376 to 0.377 clearly revealing the upward bias associated with the application of OLS to the AR persistence model. Those future profit persistence studies which are based on AR panel models should therefore apply the GMM estimator. Finally, it tends to be important to control for characteristics related to firms` strategic behavior or resource endowment as the inclusion of firm size and risk measures to the AR persistence model has a significant impact on reported $\hat{\lambda}$-values.

Hence, assuming that the 'best practice' in profit persistence research is to apply the GMM estimator and to include a full set of explanatory firm-level variables our MRA model with author cluster robust standard errors (column (4)) predicts (for a post 2003 sample with a time series dimension of 15 years) a $\hat{\lambda}$-value of 0.228 for firms in developed countries that do not operate in the food or banking sector.

From the perspective of antitrust policy the revealed moderate degree of profit persistence suggests that competition is in general fairly high and that interventions are not necessary. However, this might not hold for industries in developing countries.

The main limitation of the MRA framework is that it cannot detect misspecification which is common to all studies. An example is the fact that with the exception of Hirsch and Gschwandtner (2013) and Hirsch and Hartmann (2014) none of the observed studies include micro sized firms. However, as profit persistence is expected to be lower for micro-sized firms this likely leads to an overestimation of 'true' profit persistence by the MRA. Moreover, we are only able to explain up to $38 \%$ of the variance in reported $\hat{\lambda}$-values and it cannot be excluded that the remaining variation is caused by undetected misspecification. 


\section{Notes}

${ }^{1}$ Although some of those studies are based on panel data they do not focus on the dynamics of profits over time. Moreover, the time series dimension of the analyzed panels is with 5 years or less rather short.

${ }^{2}$ A few studies also use average sample profitability or zero as the proxy for the competitive norm (Hirsch 2014). However, throughout the persistence literature average industry profitability has usually been applied as a more realistic empirical proxy for the competitive norm (e.g. McGahan and Porter, 2003; Schumacher and Boland, 2005).

${ }^{3}$ In cases of missing precision values some MRA authors have directly contacted authors of primary studies (e.g. Oczkowski and Doucouliagos, 2014). However, in the present case this did not appear meaningful for several reasons. First and foremost, from an econometric point of view comparability of those initial AR studies to more recent panel approaches, which constitute the core profit persistence literature, is not given as the former only refer to single firms. Moreover, the fact that the initial AR time series approach yields values for each individual firm leads to a large bulk of data which is likely impossible to obtain as many of those studies have been published more than 25 years ago. In total 22 initial AR studies have been excluded.

${ }^{4}$ While the profit persistence literature usually focuses on abnormal profits it needs to be considered that abnormal losses can also persist. If the competitive norm is close to zero it is likely that abnormal losses indicate real economic losses. If sunk costs do not constitute a barrier to exit firms leave the market and persistence of abnormal losses is close to zero. On the other hand if the competitive norm is considerably above zero a firm that generates abnormal losses does not necessarily make real economic losses. In this case it might very well be possible that abnormal losses persist. Thus it is meaningful to assume that persistence only refers to economic profits which however can constitute abnormal losses.

${ }^{5}$ However, it remains unclear whether results where $\hat{\lambda} \leq-1$ or $\hat{\lambda} \geq 1$ are simply not reported due to their unreasonable interpretation or if such values indeed do not occur.

${ }^{6}$ For a more detailed technical description of the GMM-system and GMM-difference estimators we refer to Baltagi (2008).

${ }^{7}$ It has to be kept in mind that - although less likely - private firms can also be of large scale. Thus, the public variable, as the only available measure for firm size, is only a rough proxy.

8 There has been an extensive debate on the usefulness of accounting profit measures as those values can be biased due to e.g. profit smoothing or cross subsidization of less successful subsidiaries (e.g. Fisher and McGowan, 1983; Long and Ravenscraft, 1984; Biddle et al., 1997; Hirsch, 2014).

${ }^{9}$ Kim et al. (2014) point out that in cases of bi-directional publication bias an additional correlation between reported estimates and their standard errors is present rendering the standard FAT-PET approach invalid.

${ }^{10}$ We neglect the possibility of publication bias towards $\hat{\lambda}=0$ as $91.1 \%$ of the 413 included $\hat{\lambda}$ coefficients are statistically different from zero.

11 According to Angrist and Pischke (2008) the threshold number of clusters to apply robust clustered standard errors is 42. As we only have 29 author related clusters the wild bootstrap specification is applied as a robustness check.

12 The median number of observations per author in our sample is four. Moreover, of the 29 author clusters five consist of a single observation only.

13 Those results are available upon request.

${ }^{14}$ Intraclass correlation of standard errors for author clusters equals 0.40 which highlights the importance to use adjusted standard errors. 


\section{References}

Alarcon, S. and Sanchez, M. (2013) External and Internal R\&D, Capital Investment and Business Performance in the Spanish Agri-Food Industry. Journal of Agricultural Economics 64(3): 654-675.

Amidu, M. and Harvey, S.K. (2015) The persistence of profits of banks in Africa. Review of Quantitative Finance and Accounting DOI: 10.1007/s11156-014-0495-8.

Angrist, J.D. and Pischke, J.-S. (2008) Mostly Harmless Econometrics: An Empiricist's Companion. Princeton: Princeton University Press.

Arellano, M. and Bond, S. (1991) Some tests of specification for panel data: Monte Carlo evidence and an application to employment equations. Review of Economic Studies 58(2): 277-297.

Arellano, M. and Bover, O. (1995) Another look at the instrumental variable estimation of error-components models. Journal of Econometrics 68: 29-51.

Bakucs, Z., Falkowski, J. and Fertö, I. (2014) Does Market Structure Influence Price Transmission in the Agro-food Sector? A Meta-analysis Perspective. Journal of Agricultural Economics 65(1): 1-25.

Bain, J.S. (1956) Barriers to new Competition. Cambridge, MA: Harvard University Press.

Baltagi, B.H. (2008) Econometric Analysis of Panel Data. Chichester, UK: John Wiley \& Sons.

Barney, J.B. (1991) Firm Resources and Sustained Competitive Advantage. Journal of Management 17(1): 99-120.

Bhargava, S. (1994) Profit Sharing and the Financial Performance of Companies: Evidence from U.K. Panel Data. The Economic Journal 104(426): 1044-1056.

Bhattacharya, M. (2007) Industrial Performance and Competition: The Case of Japanese manufacturing. Pacific Economic Review 12(5): 619-630.

Biddle, G.C., Bowen, R.M. and Wallace, J.S. (1997) Does EVA beat earnings? Evidence on associations with stock returns and firm values. Journal of Accounting and Economics 24(3): 301-336.

Blundell, R. and Bond, S. (1998) Initial conditions and moment restrictions in dynamic panel data models. Journal of Econometrics 87: 115-143.

Bom, P.R.D. and Ligthart, J.E. (2009) How Productive is Public Capital? A Meta-Regression Analysis. Working paper 09-12 International Studies Program, Georgia State University.

Cable, J.R. and Jackson, R.H.G. (2008) The Persistence of Profits in the Long Run: A New Approach. International Journal of the Economics of Business 15(2): 229-244.

Cable, J.R. and Mueller, D.C. (2008) Testing for Persistence of Profits' Differences Across Firms. International Journal of the Economics of Business 15(2): 201-228.

Cameron, A.C., Gelbach, J.B. and Miller, D.L. (2008) Bootstrap-based Improvements for Inference with Clustered Errors. The Review of Economics and Statistics 90(3): 414-427.

Card, D. and Krueger, A.B. (1995) Time-Series Minimum-Wage Studies: A Meta-Analysis. The American Economic Review 85(2): 238-243.

Card, D., Kluve, J. and Weber, A. (2010) Active Labour Market Policy Evaluations: A MetaAnalysis. The Economic Journal 120: 452-477.

Carlton, D.W. and Perloff, J.M. (2005). Modern Industrial Organization. Boston, MA: Pearson Addison-Wesley.

Chacar, A. and Vissa, B. (2005) Are Emerging Economies Less Efficient? Performance Persistence and the Impact of Business Group Affiliation. Strategic Management Journal 26: 933-946.

Chaddad, F.R. and Mondelli, M.P. (2013) Sources of Firm Performance Differences in the US Food Economy. Journal of Agricultural Economics 64(2): 382-404. 
Crespo Cuaresma, J. and Gschwandtner, A. (2008) Explaining the persistence of profits: A time varying approach. Working Paper N0: 0806, Department of Economics University of Vienna.

Demena, B.A. and van Bergeijl, P.A.G. (2016) A Meta-Analysis of FDI and Productivity Spillovers in Developing Countries. Journal of Economic Surveys DOI: 10.1111 joes. 12146

DerSimonian, R. and Laird, N. (1986) Meta-analysis in clinical trials. Controlled Clinical Trials 7(3): 177-188.

Dickerson, A.P., Gibson, H.D. and Tsakalotos, E. (1997) The Impact of Acquisitions on Company Performance: Evidence from a Large Panel of UK Firms. Oxford Economic Papers 49(3): 344-361.

Dietrich, A. and Wanzenried, G. (2011) Determinants of bank profitability before and during the crisis: Evidence from Switzerland. Journal of International Financial Markets, Institutions and Money 21(3): 307-327.

Doucouliagos, H., Laroche, P. and Stanley, T.D. (2005) Publication Bias in UnionProductivity Research? Relations industrielles / Industrial Relations 60(2): 320-347.

Doucouliagos, H., and Stanley, T.D. (2009) Publication Selection Bias in Minimum-Wage Research? A Meta-Regression Analysis. British Journal of Industrial Relations 47(2): 406428.

Droucopoulos, V. and Lianos, T.P. (1993) The Persistence of profits in the Greek manufacturing industry, 1963-88. International Review of Applied Economics 7(2): 163176.

Eklund, J.E. and Wiberg, D. (2008) R\&D and the Persistence of Profits. The Icfai Journal of Managerial Economics 6(2): 40-54.

Elsayed, K. and Paton, D. (2005) The impact of environmental performance on firm performance: static and dynamic panel data evidence. Structural Change and Economic Dynamics 16: 395-412.

Fisher, F.M. and McGowan, J.J. (1983) On the Misuse of Accounting Rates of Return to Infer Monopoly Profits. American Economic Review 73(1): 82-97.

Geroski, P.A. and Jacquemin, A. (1988). The persistence of profits: A European comparison. The Economic Journal 98(391): 375-389.

Geroski, P.A. (1990). Modeling persistent profitability. In D.C. Mueller (ed.) The dynamics of company profits (pp. 15-34). Cambridge, UK: Cambridge University Press.

Geroski, P., Machin, S., and Van Reenen, J. (1993) The Profitability of Innovating Firms. The RAND Journal of Economics 24(2): 198-211.

Giotopoulos, I. (2014) Dynamics of Firm Profitability and Growth: Do Knowledge-Intensive (Business) Services Persistently Outperform? International Journal of the Economics of Business 21(3): 291-319.

Glen, J., Lee, K. and Singh, A. (2001) Persistence of profitability and competition in emerging markets. Economic Letters 72(2): 247-253.

Goddard, J., Molyneux, P., and Wilson, J.O.S. (2004a) The profitability of European Banks: A Cross-Sectional and Dynamic Panel Analysis. The Manchester School 72(3): 363-381.

Goddard, J., Molyneux, P., and Wilson, J.O.S. (2004b) Dynamics of Growth and Profitability in Banking. Journal of Money, Credit and Banking 36 (6): 1069-1090.

Goddard, J.A., Tavakoli, M. and Wilson, J.O.S. (2005) Determinants of profitability in European manufacturing and services: evidence from a dynamic panel model. Applied Financial Economics 15(18): 1269-1282.

Goddard, J., Liu, H., Molyneux, P. and Wilson, J.O.S. (2011) The persistence of bank profit. Journal of Banking and Finance 35: 2881-2890. 
Goddard, J., Liu, H., Molyneux, P. and Wilson, J.O.S. (2013) Do Bank Profits Converge? European Financial Management 19(2): 345-365.

Goddard, J., Tavakoli, M. and Wilson, J.O.S. (2009) Sources of variation in firm profitability and Growth. Journal of Business Research 62: 495-508.

Gschwandtner, A. (2012) Evolution of profit persistence in the USA: Evidence from three periods. The Manchester School 80(2): 172-209.

Gschwandtner, A. and Hirsch, S. (2015) Abnormal firm profitability: a comparison of the US and EU food processing industry. Mimeo University of Bonn.

Hedges, L.V. and Olkin, I. (1985) Statistical Methods for Meta-analysis. Orlando, FL: Academia Press.

Hirsch, S. (2014) Abnormal profits and profit persistence: evidence from the European food industry. Dissertation University of Bonn.

Hirsch, S. and Gschwandtner, A. (2013) Profit persistence in the food industry: evidence from five European countries. European Review of Agricultural Economics 40(5): 741-759.

Hirsch, S. and Hartmann, M. (2014) Persistence of firm-level profitability in the European dairy processing industry. Agricultural Economics 45(S1): 53-63.

Hirsch, S., Schiefer, J., Gschwandtner, A. and Hartmann, M. (2014) The determinants of firm profitability differences in EU food processing. Journal of Agricultural Economics 65(3): 703-721.

Jarrell, S.B. and Stanley, T.D. (1990) A Meta-Analysis of the Union-Nonunion Wage Gap. Industrial \& Labor Relations Review 44: 54-67.

Kim, J., Doucouliagos, H. and Stanley, T.D. (2014) Market Efficiency in Asian and Australasian Stock Markets: A Fresh Look at the Evidence. DEAKIN University Australia, School of Accounting, Economics and Finance, Economics Series Working Paper SWP 2014/9.

Levonian, M.E. (1994) The Persistence of Bank Profits: What the Stock Market Implies. Economic Review - Federal Reserve Bank of San Francisco 2: 3-17.

Lima, M.A.M. and Resende, M. (2004) Profit margins and business cycles in the Brazilian industry: a panel data study. Applied Economics 36(9): 923-930.

Liu, H. and Wilson, J.O.S. (2010) The profitability of banks in Japan. Applied Financial Economics 20(24): 1851-1866.

Long, W.F and Ravenscraft, D.J (1984) The Misuse of Accounting Rates of Return: Comment. The American Economic Review 74(3): 494-500.

Longhi, S., Nijkamp, P. and Poot, J. (2005) A Meta-Analysis Assessment of the Effect of Immigartion on Wages. Journal of Economic Surveys 19(3): 451-477

Matyjas (2014) Industry and Firm Influences on Performance: Evidence from Polish Public Firms. Journal of Management Policy and Practice 15(2): 88-96.

McGahan, A.M. and Porter, M.E. (1997) How much does industry matter really? Strategic Management Journal 18: 15-30.

McGahan, A.M. and Porter, M.E. (1999) The Persistence of Shocks to Profitability. The Review of Economics and Statistics 81(1): 143-153.

McGahan, A.M. and Porter, M.E. (2003) The emergence and sustainability of abnormal profits. Strategic Organization 1(1): 79-108.

MacKinnon, J.G. and Webb, M.D. (2016) Wild Bootstrap Inference for Wildly Different Cluster Sizes. Journal of Applied Econometrics DOI: 10.1002/jae.2508.

McNamara, G., Vaaler, P.M. and Devers, C. (2003) Same as it ever was: The search for evidence of increasing Hypercompetition. Strategic Management Journal 24: 261-278.

Mueller, D.C. (1977) The persistence of profits above the norm. Economica 44(176): 369380.

Mueller, D.C. (1986) Profits in the Long Run. Cambridge, UK: Cambridge University Press. 
Nakano, A. and Kim; D. (2011) Dynamics of Growth and Profitability: The Case of Japanese Manufacturing Firms. Global Economic Review: Perspectives on East Asian Economies and Industries 40(1): 67-81.

Nelson, J.P. and Kennedy, P.E. (2009) The Use (and Abuse) of Meta-Analysis in Environmental and Natural Resource Economics: An Assessment. Environmental and Resource Economics 42(3): 345-377.

Nunes, P.J.M., Serrasqueiro, Z.M. and Sequeira, T.N. (2009) Profitability in Portuguese service industries: a panel data approach. The Service Industries Journal 29(5): 693-707.

Oczkowski, E. and Doucouliagos, H. (2014) Wine Prices and Quality Ratings: a MetaRegression Analysis. American Journal of Agricultural Economics 97(1): 103-121.

Odagiri, H. and Yamawaki H. (1990) The persistence of profits in Japan. In D. C. Mueller (ed.) The dynamics of company profits (pp. 129-146). Cambridge, UK: Cambridge University Press.

Ollinger, M., MacDonald, J. and Madison, M. (2000) Poultry plants lowering production costs and increasing variety. Food Review (22): 2-7.

Pattitoni, P., Petracci, B. and Spisni, M (2014) Determinants of profitability in the EU-15 area. Applied Financial Economics 24(11): 763-775.

Pervan, M., Pelivan, I. and Arnerić, J. (2015) Profit persistence and determinants of bank profitability in Croatia. Economic Research-Ekonomska Istraživanja 28(1): 284-298.

Porter, M.E. (1980) Competitive Strategy, Techniques for Analyzing Industries and Competitors. New York: The Free Press.

Roberts, P.W. (1999) Product Innovation, Product-Market Competition and Persistent Profitability in the U.S. Pharmaceutical Industry. Strategic Management Review 20: 655670.

Rumelt, R.P. (1991) How much does industry matter? Strategic Management Journal 12(3): 167-185.

Saona Hoffmann, P. (2011) Determinants of the Profitability of the US Banking Industry. International Journal of Business and Social Science 2(22): 255-269.

Schmalensee, R. (1985). Do markets differ much? The American Economic Review 75(3): 341-351.

Schmidt, N. (2014) The Determinants of Firm Profitability: The Effect of Social Media. CMC Senior Theses. Paper 958.

Schohl, F. (1990) Persistence of Profits in the Long Run. A Critical Extension of Some Recent Findings. International Journal of Industrial Organization 8: 385-404.

Schumacher, S.K. and Boland, M.A. (2005) The persistence of profitability among firms in the food economy. American Journal of Agricultural Economics 87(1): 103-105.

Schwalbach, J., Grasshoff, U. and Mahmood, T. (1989). The dynamics of corporate profits. European Economic Review 33(8): 1625-1639.

Shehzad, C.T., De Haan, J. and Scholtens, B. (2009) Growth and Earnings Persistence in Banking Firms: A Dynamic Panel Investigation. CESIFO Working Paper No. 2772

Short, J.C., Ketchen, D.J., Bennett, N., and du Toit, M. (2006) An Examination of Firm, Industry, and Time Effects on Performance Using Random Coefficients Modeling, Organizational Research Methods 9: 259-284.

Stanley, T.D. (2001) Wheat from Chaff: Meta-Analysis as Quantitative Literature Review. The Journal of Economic Perspectives 15(3): 131-150.

Stanley, T.D. (2005) Beyond Publication Bias. Journal of Economic Surveys 19(3): 309-345.

Stanley, T.D. (2008) Meta-Regression Methods for Detecting and Estimating Empirical Effects in the Presence of Publication Selection. Oxford Bulletin of Economics and Statistics 70(1):103-127. 
Stanley, T.D. and Jarrell, B. (1989) Meta-Regression Analysis: A Quantitative Method of Literature Surveys. Journal of Economics Surveys 19(3): 161-170.

Stanley, T.D. and Doucouliagos, H. (2010) Picture This: A Simple Graph That Reveals Much Ado About Research. Journal of Economic Surveys 24(1): 170-191.

Stanley, T.D. and Doucouliagos, H. (2012) Meta-regression Analysis in Economics and Business. Oxford, UK: Routledge.

Stanley, T.D. and Doucouliagos, H. (2013) Better than Random: Weighted Least Squares Meta Regression Analysis. DEAKIN University Australia, School of Accounting, Economics and Finance, Economics Series Working Paper SWP 2013/2.

Stanley, T.D., Doucouliagos, H., Giles, M., Heckemeyer, J.H., Johnston, R.J., Laroche, P., Nelson, J.P., Paldam, M., Poot, J., Pugh, G., Rosenberger, R.S. and Rost, K. (2013) MetaAnalysis of Economics Research Reporting Guidelines. Journal of Economic Surveys 27(2): 390-394.

Stephan, A. and Tsapin, A. (2008) Persistence and determinants of firm profit in emerging markets. Applied Economics Quarterly 54: 231-253.

Tsoulfidis, L., Alexiou, C. and Parthenidis, T. (2015) Revisiting profit persistence and the stock market in Japan. Structural Change and Economic Dynamics 33: 10-24.

Valickova, P., Havranek, T. and Horvath, R. (2015) Financial Development and Economic Growth: A Meta-Analysis. Journal of Economic Surveys 29(3): 506-526.

Villalonga, B. (2004) Intangible resources, Tobin's q, and sustainability of performance differences. Journal of Economic Behavior \& Organization 54: 205-230.

Wang, K. and Shailer, G. (2015) Ownership Concentration and Firm Performance in Emerging Markets: A Meta-Analysis. Journal of Economic Surveys 29(2): 199-229.

Wijnands, J.H.M., Meulen, B.M.J. van der and Poppe, K.J. (2007) Competitiveness of the European Food Industry: An economic and legal assessment 2007. Luxembourg: European Commission.

Yurtoglu, B.B. (2004) Persistence of firm-level profitability in Turkey. Applied Economics 36(6): 615-625.

Zigraiova, D. and Havranek, T. (2015) Bank Competition and Financial Stability: Much Ado about Nothing. Journal of Economic Surveys DOI: 10.1111/joes.12131. 